\title{
肩腱板断裂に対する超音波検查法の有用性
}

\author{
整形外科前原病院 \\ 松 元 光 生・下 野 哲 朗 \\ 福 田稔 朗・前 原 東 洋 \\ 鹿児島大学整形外科 \\ 酒匂崇

\section{Ultrasonographic Evaluation of Therotator Coff Tear} \\ by

\section{Kosei Matsumoto, Tetsuro Shimono, Toshiro Fukuda and Toyo Maehara} \\ Orthopaedic Maehara Hospital, Miyazaki \\ Takashi Sakou \\ Department of Orthopaedic Surgery, \\ Factory of Medicine, Kagoshima University, Kagoshima

\begin{abstract}
Ultrasonography of the shoulder joint was investigated in 30 patients who had been suspected rotator cuff tear. In 26 patients, the sonographic fihdings were correlated with arthrography (sensitivity, $86 \%$ ).

The sonographic appearance of the rotator coff tear, be could be classified into three, categories as thinning (15 patients), invisualization (8 patients), and discontinuity (3 patients) of the rotator cuff. Based on these results, ultrasonography is comparable with arthrography for evaluation of the rotator cuff, so we think that ultrasonography can be used as the intial imaging test for the rotator cuff tear.
\end{abstract}

\section{は じめに}

超音波検査法は，内科・外科・産婦人科などでさか んに行われているが, 整形外科領域でも最近その有用 性が報告されている，肩腱板断裂の画像診断は，関節 造影が主役をなしているが，われわれはその補助診断 として超音波検査を行ない, その有用性について検討 したので報告する。

\section{症例および方法}

症例は，腱板断裂が疑われ，超音波検査を行った 30 例 30 肩関節である. 症例の内訳は, 男 19 例, 女 11 例, 右 21 例，左 9 例，年齢は $40 \sim 81$ 才 (平均 65 才) であ
る. 超音波検査は, 横断像, 縦断像の 2 方向 scan を, 原則として両側の肩関節に施行した。腱板断裂の確定 診断は, 関節造影にて行い, うち 6 例に手術を施行し た. 使用装置は, アロカ・エコーカメラ SSD-630, 周 波数は $7.5 \mathrm{MHz}$ である.

$7.5 \mathrm{MHz}$ の探触子では, 腱板実質の観察は可能では あるが, 全例において腱板の上・下面が明瞭に抽出さ れる訳ではない.そこで, 肩峰下包上腕骨頭間距離 $(\mathrm{SABHD})^{1) 5)}$ を用い, 目安としての腱板の厚さを計測 し，腱側と患側で比較を行った。

結

果

手術所見および関節造影との比較で，腱板断裂と確 


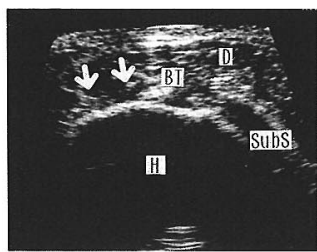

患側

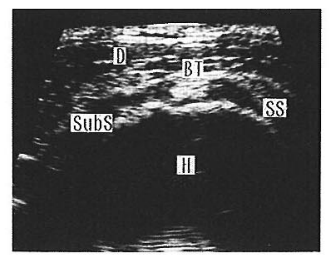

健側

図 1 症例 1.48 才男性. 横断像における棘上筋腱の 消失像である，患側にて棘上筋腱は消失してい る (矢印)。 D : 三角筋 BT : 二頭筋長頭腱 $\mathrm{SS}$ ：棘上筋 腱 SubS：肩甲下筋腱 $\mathrm{H}$ ：上腕骨頭

認出来た 30 症例中 26 例（87％）に超音波検查にて異 常所見を認めた。超音波所見は，腱板の菲薄化 15 例， 消失 8 例, 不連続 3 例であった. 超音波検查にて正常 像を呈した 4 例中 2 例は，関節造影にて，大結節の外 側縁に ulcer 様の陰影を認め, deep surface tear が疑 われた。残りの 2 例は, 関節造影にて, 肩峰下滑液包 への造影剂の流出を認めた。

健側 30 肩関節の超音波所見は, 27 例で均一な echogenicity を示したが， 3 例で腱内の高エコーバン ド様の不連続像を呈した。SABHD は，5〜8 mm (6.1 $1.0 \mathrm{~mm})$ であった。一方, 腱板の菲薄化像を 呈した 15 例では SABHDは 2〜 $5 \mathrm{~mm}(4.1 \pm 0.9$ $\mathrm{mm}$ )で，健側に比し有意に減少していた。健側との差 は， $2 \mathrm{~mm}$ を呈する症例が 10 例ともっともも多く，3 $\mathrm{mm}$ の差を呈する症例が 3 例, $4 \mathrm{~mm}$ および $1 \mathrm{~mm}$ の 差を呈する症例がそれぞれ 1 例ずつをしめた。また， 腱板の消失像を呈した症例では SABHD は $1 \mathrm{~mm}$ 以下で あり，不連続像を呈する症例は計測が困難な場合が多 かった。

術前・術後の超音波像の比較では，中等度 (三角形・ 縦）断裂の 2 例は術後ほぼ正常像を呈したが, 広範囲 断裂の 3 例は, 術後も術前と同様な超音波像を呈した。

\section{症 例 供 覧}

症例 $1: 48$ 才男性. 打撲による右局腱板断裂。超音 波検查にて, 棘上・棘下筋腱におよぶ腱板の消失像を 認め,術中も同様な広範囲断裂を確認している(図 1)。 症例 $2: 62$ 才男性。打撲による右肩腱板断裂。超音波 検查では，棘上等腱の菲薄化像を呈した。術中所見は， 棘上筋腱単独の三角形断裂であった（図 2 ).

症例 $3: 65$ 才男性。打撲に上る左肩腱板断裂。超音波

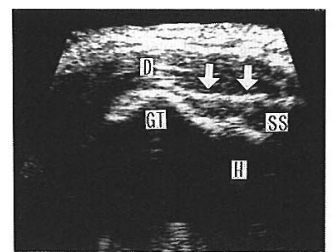

患側

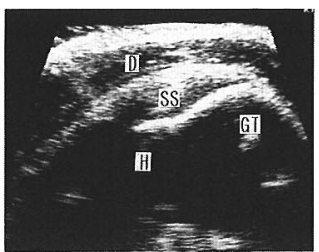

健側
図2 症例 2.62 才男性。綐断像に㧍ける棘上筋腱の 菲薄化像である. 棘上筋腱の厚さは, 健側の 6 $\mathrm{mm}$ に比し. 患側では $3 \mathrm{~mm}$ と菲薄化を呈して いる (矢印)。

GT：大結節 他は図 1 と同じである。

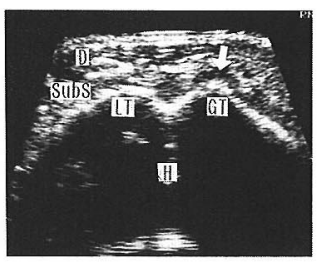

患側

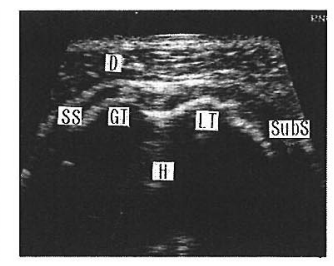

健側
図 3 症例 3.65 才男性. 横断像における棘上筋腱の 不連続像である.患側にて, 腱内の echogenicity が不均一である (矢印).

LT : 小結節 他は図 $1 ， 2$ と同じである.

検査では，棘上筋腱の不連続像を呈し，関節造影にて 造影剤の肩峰下滑液包への流出を認めた。保存的治療 を行った（図 3 )

考察

肩腱板断裂に対する超音波検查は， $\mathrm{Mack}^{22}$, Middleton ${ }^{3)}$, Crass ら ${ }^{4)}$ の報告があるが,いずれもその 診断率 (sensitivity) は 90 \%以上である。

Middleton ら ${ }^{3)}$ は, 100 例の超音波検査の中で, 腱板 の消失像 (non-visualization) や菲薄化像 (thinning) を呈した 21 例全例で, 関節造影にて腱板断裂を確認し ているが，不連続像 (discontinuity) や central echogenic band を呈した 16 例中 6 例は，false positiveであったとしている。また, false negativeは 3 例 あったとし，その要因として，経験や技術的な面が関 与すると述べている。われわれは, central echogenic band の症例は経験していないが，不連続像は 60 肩関 節中 6 例認めており，うち 3 例は健側の肩関節であっ た. 不連続像は false positive の可能性があり，その診 断価值は消失像や菲薄化像に比べて低いと言えるであ 
ろう。一方, 消失像や菲薄化像は 23 例で認めたが, 全 例 true positive であった。消失像を呈した 3 例に手術 を行い,いずれも広範囲断裂を確認したが, Middleton $ら^{3)}$ も消失像では $3 \mathrm{~cm}$ 以上の断裂である可能性が高い としている. また, 菲薄化像を呈した 3 例は, 中等度

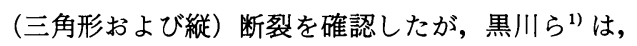
SABHD が $4 \mathrm{~mm}$ 以下であれば, 腱板の広範囲断裂あ るいは腱板の中等度以上の引き込みを伴う断裂と診断 出来るとしている. 腱板の消失像は, 菲薄化像が高度 になったと考えられるので，超音波検査においてこれ らの所見が得られれば，腱板断裂が強く疑われょう。

超音波検査の利点は, 患者に侵襲を与えないこと, 安全かつ迅速に, 画像診断を real time に行いうること であるが，関節造影にて診断が困難な不全断裂の診断 に有用との報告も多い.Crass ら ${ }^{4)}$ は, 超音波像と手術 所見との比較を行った腱板断裂 9 例の中で， 1 例に関 節造影にて診断出来なかった不全断裂を認めており, その超音波像は腱内の echogenicity の増加であったと 述べている.また黒川ら ${ }^{1)}$ は, 滑液包面断裂の 6 例中 3 例に central echogenic band をみとめている。われわ れは，関節造影にて関節包面断裂が疑われた 2 例を経 験しているが, 超音波にて eshogenicity の変化は認め ていない.

術後の超音波像は, 3 例がいずれも術前と同様な超 音波像を呈したが，これらはいずれも広範囲断裂であ つたため,その手術侵襲および術後の痖着によるもの が原因と推測している.

$$
\text { ま と め }
$$

1. 肩関節造影にて肩腱板断裂と診断された 30 症例
のうち，超音波検査にて 26 例 (87\%) に腱板の菲薄化 像, 消失像, 不連続像を認めた。

2. 6 例に手術を行い, 消失像は広範囲断裂, 菲薄 化像は中等度（三角形および縦）断裂と確認した。

3. 超音波検查は, 肩腱板断裂のスクリーニングと して有用な検査である.

\section{参 考 文 献}

1）黑川正夫・ほか: 肩腱板断裂の超音波診断. 整形・災 外, $30: 791-798,1987$.

2) Mack LA et al.: US evaluation of the rotator cuff. Radiology 157 : 205-, 1985.

3) Middleton WD et al.: Ultrasonographic evaluation of the rotator cuff and biceps tendon. J Bone Joint Surg 68-A : 440-450, 1986.

4) Crass JR et al.: Ulrasonography of the rotator cuff : surgical correlation.J Clin Ultrasound 12: 487 $-492,1985$.

5）黒川正夫・ほか：超音波断層法による肩腱板の形態。 肩関節, $10: 46-48,1986$.

解 答前原病院 松元 光生

(1) 棘上筋腱の肢位はどのようにしているか.

外施位で測定している（動態で観察しながら, 解剖 頝の notch がみえるところで測定している)

(2) どの位までの小断裂まで測定可能か. 今回は小断裂の手術症例は経験していない.

(3) false positiveの症例は何例認めたか.

健側 30 例中 3 例に false positive を認め, いずれも 不連続像を呈した。 